\title{
Effect of COVID-19 on the Job Security and Employee Loyalty in the Oil and Gas Sectors in the Sultanate of Oman
}

\author{
Ahmed Ali Alalawi, Nadia Farhana, Asif Mahbub Karim
}

To Link this Article: http://dx.doi.org/10.6007/IJARAFMS/v11-i3/11195 DOI:10.6007/IJARAFMS /v11-i3/11195

Received: 14 July 2021, Revised: 17 August 2021, Accepted: 30 August 2021

Published Online: 20 September 2021

In-Text Citation: (Alalawi et al., 2021)

To Cite this Article: Alalawi, A. A., Farhana, N., \& Karim, A. M. (2021). Effect of COVID-19 on the Job Security and Employee Loyalty in the Oil and Gas Sectors in the Sultanate of Oman. International Journal of Academic Research in Accounting Finance and Management Sciences, 11(3), 661-669.

Copyright: (c) 2021 The Author(s)

Published by Human Resource Management Academic Research Society (www.hrmars.com)

This article is published under the Creative Commons Attribution (CC BY 4.0) license. Anyone may reproduce, distribute, translate and create derivative works of this article (for both commercial and non-commercial purposes), subject to full attribution to the original publication and authors. The full terms of this license may be seen at: http://creativecommons.org/licences/by/4.0/legalcode

Vol. 11, No. 3, 2021, Pg. 661 - 669

Full Terms \& Conditions of access and use can be found at http://hrmars.com/index.php/pages/detail/publication-ethics 


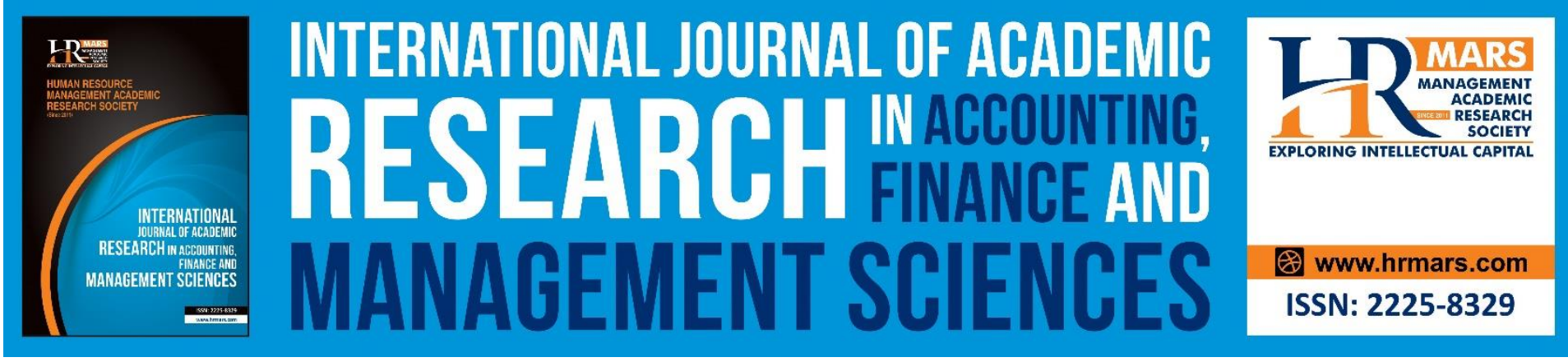

\title{
Effect of COVID-19 on the Job Security and Employee Loyalty in the Oil and Gas Sectors in the Sultanate of Oman
}

\author{
Ahmed Ali Alalawi \\ Binary University of Management and Entrepreneurship, Selangor, Malaysia \\ Dr. Nadia Farhana \\ Stamford University Bangladesh, Dhaka, Bangladesh \\ Dr. Asif Mahbub Karim \\ Binary University of Management and Entrepreneurship, Selangor, Malaysia \\ Email: alalawi.ahmed.ali@gmail.com
}

\begin{abstract}
Oil and gas industries often face significant competition worldwide and are now undergoing fast and widespread environmental alignment. The worldwide downturn in the oil and gas industry has had a remarkable effect on the Middle East market. Companies are struggling to maintain job security as well as employee loyalty during the COVID-19 pandemic. Employee loyalty is critical to the growth of the firm's productivity and quality. Employees' primary worry is job security. While job satisfaction is primarily concerned with the employee's attitude toward their present employment, employee loyalty examines a broader context, namely the employee's attitude toward the company. Job happiness is a predictor of employee loyalty. Employees who are happy with their employment are more likely to be loyal to the company than those who are unsatisfied. The main objective of this paper is to evaluate the impact of employee loyalty, job security, and their relation in the oil and gas industry of Oman amid the COVID-19 pandemic. The Social Studies Statistics Program was utilized to provide analytical responses to the study's questions. SPSS model version 23 was used to evaluate the questionnaire data. It has been found that the majority of respondents in the Sultanate of Oman's oil and gas sectors endorsed the company's employee loyalty and job security during the COVID-19 period. Additionally, the Pearson correlation coefficient and multiple regression analysis indicate an apparent positive relationship between employee loyalty and job security in the Sultanate of Oman's oil and gas industry during the COVID-19. Additional studies can be carried out in the future related to other management-related matters in the Oil and Gas Sectors during as well as after the COVID period.
\end{abstract}

Keywords: Employee Loyalty, Job Security, Oil and Gas Sectors, Sultanate of Oman, Questionnaire. 


\section{Introduction}

COVID-19 originated in the Chinese city of Wuhan. COVID-19 spread with breakneck speed and has not yet been eradicated. Numerous studies on COVID-19 and its detrimental effects have been conducted so far. This article discusses a few of them briefly. Fraudulent COVID-19 tests represent a severe danger to public health (Hossain et al., 2021). Additionally, they recommended properly identifying infected people to segregate them due to coronavirus's fast spread. Meanwhile, during COVID-19, sexual violence was acknowledged as a severe social and mental health problem and the most prevalent crime against humanity (Rabby et al., 2021). Consequently, it was recommended that suitable preventive and punitive measures be implemented to stop the increasing trend of violence directed towards women. Besides, Yuki et al (2020) argued that developing customized therapies is essential. Simultaneously, elucidating the distinctions between juvenile and adult responses to this virus may help develop tailored immune-based treatments. Additionally, Rabby et al (2020) conducted cross-sectional research and suggested that fundamental knowledge, comprehension, and judgment be recognized and enhanced in order to minimize COVID-19 transmission in the community.

The oil and gas sector has long been seen as one with highly competitive barriers worldwide and is now undergoing fast and widespread environmental alignment. The growth of the oil and gas industry is contingent upon the availability of skilled workers and the caliber of professional engineers (Lee, 2012). According to Mehta et al (2010), loyalty may be regarded to manifest itself via actions that demonstrate the belief and emotional component that contribute to its development. According to the Dow Jones Sustainability Index (2012), the oil and gas industry may be dangerous and environmentally unfriendly, resulting in poor employee loyalty and satisfaction. Meanwhile, Gilbert and Veloutsou (2006) stated that the behaviors and actions of an employee might influence a customer's perception of a company. Businesses invest large amounts of money to gain customer loyalty but often neglect the critical aspect of inspiring workers to accomplish their non-financial and financial objectives. Employees are essential in today's competitive climate for capturing the minds and hearts of customers.

According to the Loyalty Research Center (2002), employee loyalty occurs when workers believe they have no regrets about working for the company and view it as the best choice. Employees are seen as an essential asset in many businesses since they represent vital investments. The benefits received from a company in salary, special perks, and incentives ultimately compel workers to remain loyal and work diligently for the firm. Vince (2005) said that employees must understand their coworkers' requirements in order to foster employee loyalty to the company. Indirectly or directly, the incentive system for workers is critical since it encourages people to take personal responsibility for achieving the firm's objectives and missions. Non-monetary rewards include additional time off, appreciation certificates, or presents to workers to foster their loyalty and elicit a feeling of pleasure for their hard work inside the company.

According to Appelbaum and Patton (2002), the motivation of surviving employees has become a significant issue, and steps must be taken to ensure that those who remain to prosper. Along with personnel reductions, a work redesign is necessary to modernize the firm's processes and guarantee that employees are not overworked. It is essential to create an atmosphere in which employees feel they have a viable career path. According to Newell and Dopson (1996), the complexity of the loyalty process exacerbated the losses associated 
MANAGEMENT SCIENCES

Vol. 11, No. 3, 2021, E-ISSN: 2225-8329 @ 2021 HRMARS

with low employee morale, decreased productivity, and loyalty. For example, the problems that arise during the early planning phases result in workers spending considerable time worrying and talking about what could happen if their company experiences a loyalty crisis. Communication is critical in every business since it may affect employee trust and loyalty. Numerous workers feel they will have no future opportunities since the company has shrunk, leaving them little room to grow. According to Gibson et al (2009), management authorities believe that loyalty decreases workers' loyalty to the company. A company is left with the task of reconstructing itself after a shrinking procedure.

Chew (2004) said that a feeling of job stability often helps retain workers and improves their abilities and knowledge to perform better in the workplace. According to Smith (2010), workers are always concerned about the state of the economy. It would be determined by factors like pay and benefits, job security, and their capacity to handle the economy's problem. According to Mellquist and Femermo (2007), an increase in the price of oil results in an increase in the cost of production, which affects the number of workers. Industries are reliant on oil, and rising oil prices will have a significant effect on employee loyalty. Employees rely on consumer demand or aggregate demand-a decline in order results in increased unemployment, which results in job instability. According to Ndlouvu and Parumasur (2005), many workers would create a job hierarchy and ensure the security of their personal growth in order to demonstrate their commitment to the organization's purpose and objectives. Thus, job security may be inferred to benefit employee loyalty and performance if the company concentrates appropriately on developing a solid strategy for its workers inside the organization. When issues of loyalty emerge, job loss is often unpleasant for a large number of people.

The worldwide downturn in the oil and gas industry has significantly impacted the Middle East market. Employee loyalty may be critical in increasing the firm's production and quality. Employees' primary worry is job security. Employees will eventually flee from adverse effects on their physical and psychological health as a result of this lack of job stability and anxiety. Such consequences will have a detrimental impact on workers' ability to provide and/or acceptably create service. The purpose of this study is to determine the effect of job security and employee loyalty during the COVID-19 pandemic. Additionally, the study examined the connection between job security and employee loyalty in the oil and gas industry of Oman amid the COVID-19 pandemic.

\section{Methodology}

SPSS (Statistics Program for Social Studies) was used to give analytical responses to the study questions. To analyze the questionnaire data, SPSS model version 23 was used. The total number of questionnaire responders was calculated by dividing the total number of questionnaires distributed by the total number of questionnaires distributed. The latter is a sum that excludes inaccessible contact information and related variables. The total number of questionnaire respondents was calculated by dividing the number of completed questionnaires by the total number of questionnaires sent. The final one is a sum that accounts for inaccessible contact information as well as other comparable variables. Five hundred individuals received questionnaires, and 76\% replied. Additionally, several individuals were unable to complete the surveys correctly. As a result, 346 of them were used.

\section{Questionaries}

Questionaries are represented in Table 1. 
Table 1: Questionaries related to Job Security and Employee Loyalty

\begin{tabular}{|l|l|}
\hline Job Security (JS) & Employee Loyalty (EL) \\
\hline $\begin{array}{l}\text { JS1. Lose the job and are demoted within the } \\
\text { company amid this covid-19 pandemic. }\end{array}$ & $\begin{array}{l}\text { EL1. Despite the difficulties of the covid-19 } \\
\text { pandemic, employees are willing to give extra } \\
\text { effort to ensure the organization's success. }\end{array}$ \\
\hline $\begin{array}{l}\text { JS2. Permanently lose the work and are fired off } \\
\text { amid this covid-19 period. }\end{array}$ & $\begin{array}{l}\text { EL2. Employees are willing to work properly } \\
\text { when they have to work from home during the } \\
\text { covid-19 pandemic. }\end{array}$ \\
\hline $\begin{array}{l}\text { JS3. Possibility of advancement within the } \\
\text { company amid this covid-19 situation. }\end{array}$ & $\begin{array}{l}\text { EL3. Employees are willing to inform the } \\
\text { management correctly if any unavoidable } \\
\text { situation arises due to the covid-19 pandemic. }\end{array}$ \\
\hline $\begin{array}{l}\text { JS4. Actual access to organizational resources } \\
\text { (information, materials, and people) during the } \\
\text { covid-19 pandemic. }\end{array}$ & $\begin{array}{l}\text { EL4. Employees are sincere to the organizational } \\
\text { objectives after the transformation process due } \\
\text { to the covid-19 pandemic. }\end{array}$ \\
\hline $\begin{array}{l}\text { JS5. Employees within the company can avoid } \\
\text { unfortunate incidents from influencing their } \\
\text { work environment amid this covid-19 situation. }\end{array}$ & $\begin{array}{l}\text { EL5. Employees are willing to solve work-related } \\
\text { problems individually amid the covid-19 } \\
\text { pandemic. }\end{array}$ \\
\hline $\begin{array}{l}\text { JS6. Employees have a sufficient understanding } \\
\text { of the company to influence issues affecting } \\
\text { them during this covid-19 period. }\end{array}$ & $\begin{array}{l}\text { EL6. Employees do not blame the management } \\
\text { for the situation amid the covid-19 pandemic. }\end{array}$ \\
\hline
\end{tabular}

\section{Results and Discussion Job Security}

For assessing the organization's job security during the COVID-19 pandemic, six different questions were provided in the survey. The response from the survey was summarized in Figure 1. Figure 1 demonstrated that most of the respondents supported the questions and provided a positive response. According to the survey, the highest number of respondents were strongly agreed that the individual might lose the job and be demoted within the company due to the covid-19 pandemic. Meanwhile, an employee within the company may lose their job and be laid off entirely. However, an employee may avoid bad events from influencing the work condition and support the organization enough to control those events. Moreover, the highest number of respondents were agreed that the employee has the opportunity to advance within the company and that the employee has easy access to organizational resources (information, materials, people) in the organization during the covid19 pandemic. The response of disagreed and strongly disagreed was the lowest from the respondents on the job security. Therefore, the findings reported that the employees positively supported the job security system of the company.

Table 2 represents the statistic of the job security responses from the respondents. The statistics referred that for all the job security questions, the net mean was 3.673, the net median was 4.0 , the net standard deviation was 0.997 , the net Skewness was -0.476 . The error of Skewness was 0.131, net Kurtosis was -0.58 , and net standard Error of Kurtosis was 0.261 . These all of the values represented that the responses from the respondent were positive to support the value. 


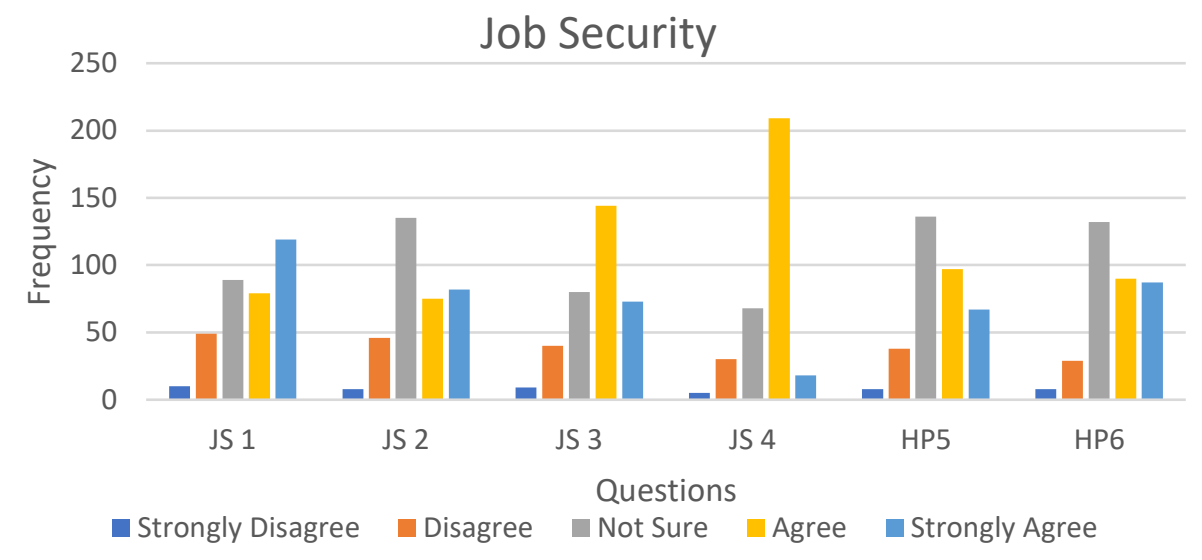

Figure 1: Job security according to response from the respondent

Table 2: Statistics of Job Security

\begin{tabular}{|l|l|l|l|l|l|l|}
\hline & JS 1 & JS 2 & JS 3 & JS 4 & JS 5 & JS 6 \\
\hline N Valid & 346 & 346 & 346 & 346 & 346 & 346 \\
Mean & 3.6243 & 3.6821 & 3.6329 & 3.7052 & 3.6792 & 3.7139 \\
Mode & 4 & 3 & 4 & 4 & 3 & 3 \\
Median & 4 & 4 & 4 & & 4 & 4 \\
Standard Deviation & 1.07022 & 1.03143 & 1.06101 & .80924 & 1.00057 & 1.00819 \\
Variance & 1.145 & 1.064 & 1.126 & .655 & 1.001 & 1.016 \\
Kurtosis & -.559 & -.478 & -.513 & -1.290 & -.320 & -.319 \\
Std. Error of Kurtosis & .261 & .261 & .261 & .261 & .261 & .261 \\
Skewness & -.419 & -.305 & -.411 & -1.064 & -.300 & -.358 \\
Std. Error of Skewness & .131 & .131 & .131 & .131 & .131 & .131 \\
Maximum & 5 & 5 & 5 & 5 & 5 \\
Minimum & 1 & 1 & 1 & 1 & 1 \\
Range & 4 & 4 & 4 & 4 & 4 & 4 \\
\hline
\end{tabular}

\section{Employee Loyalty}

To evaluate employee loyalty in the organization during the covid-19 pandemic, six different questions were provided. The response from the survey was summarized in Figure 2. Figure 2 demonstrated that most of the respondents supported the questions and provided a positive response. The highest number of respondents were strongly agreed that employees should not blame the management for the situation amid the covid-19 pandemic. Meanwhile, most respondents were not sure about proper working from home during the covid-19 pandemic. The reason behind this may be their no previous knowledge about work from home. Simultaneously, the highest number of respondents were unsure about solving workrelated problems individually amid the covid-19 pandemic. Moreover, after the transformation process due to the covid-19 pandemic, most respondents felt that employees were very committed to the organizational goals. The response of disagreed and strongly disagreed was the lowest from the respondents on employee loyalty. Therefore, the findings reported that the employees positively support the employee loyalty system of the company. 
INTERNATIONAL JOURNAL OF ACADEMIC RESEARCH IN ACCOUNTING, FINANCE AND MANAGEMENT SCIENCES

Vol. 11, No. 3, 2021, E-ISSN: 2225-8329 @ 2021 HRMARS

Table 3 represents the statistic of the employee loyalty responses from the respondents. The statistic referred that for all the questions of employee loyalty, the net mean was 3.678, the net median was 4.0, the net standard deviation was 0.9998, the net Skewness was -0.475 . The error of Skewness was 0.131; net Kurtosis was -0.58 , and the net standard error of Kurtosis was 0.261 . These all of the values represented that the responses from the respondent were positive to support the value.

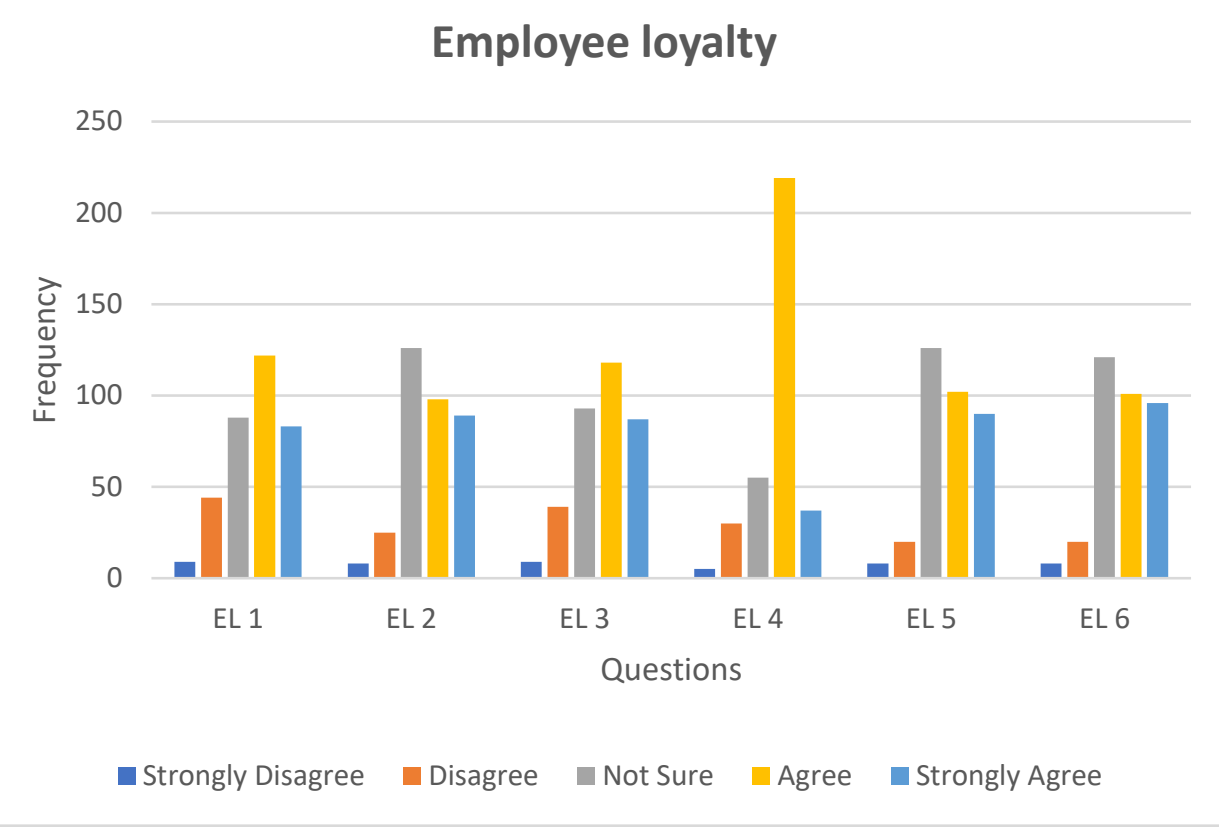

Figure 2: Employee loyalty according to response from the respondent

Table 3: Statistics of Employee Loyalty

\begin{tabular}{|l|l|l|l|l|l|l|}
\hline & & & & & & \\
& EL 1 & EL 2 & EL 3 & EL 4 & EL 5 & EL 6 \\
\hline N Valid & 346 & 346 & 346 & 346 & 346 & 346 \\
Mean & 3.6243 & 3.6879 & 3.6358 & 3.7110 & 3.6850 & 3.7225 \\
Mode & 4 & 3 & 4 & 4 & 3 & 3 \\
Median & 4 & 4 & 4 & 4 & 4 & 4 \\
Standard Deviation & 1.07022 & 1.03320 & 1.06338 & .81489 & 1.00241 & 1.01491 \\
Variance & 1.145 & 1.068 & 1.131 & .664 & 1.005 & 1.030 \\
Kurtosis & -.559 & -.481 & -.523 & -1.239 & -.324 & -.355 \\
Standard Error of Kurtosis & .261 & .261 & .261 & .261 & .261 & .261 \\
Skewness & -.419 & -.314 & -.410 & -1.040 & -.308 & -.359 \\
Standard Error of Skewness & .131 & .131 & .131 & .131 & .131 & .131 \\
Maximum & 5 & 5 & 5 & 5 & 5 & 5 \\
Minimum & 1 & 1 & 1 & 1 & 1 & 1 \\
Range & 4 & 4 & 4 & 4 & 4 & 4 \\
\hline
\end{tabular}

Pearson Correlation between Job Security and Employee Loyalty

This analysis is for the question about the possible relationship between Job security and employee loyalty. Pearson's $r$ is 0.892 in this case. This value is very near to one. This indicates that two variables have a strong connection. This implies that the importance of one variable 
MANAGEMENT SCIENCES

Vol. 11, No. 3, 2021, E-ISSN: 2225-8329 @ 2021 HRMARS

is highly linked with those in the second. As a result, we may infer that job security and employee loyalty have a significant positive connection.

Another way is looking at Sig value. If the Sig (2-Tailed) value is below or equal to .05, we may infer that those two variables have a statistically significant connection. That is, changes in one variable are related to changes in the second variable in a statistically significant way. So, job security and employee loyalty have a strong relationship.

\section{Multiple Regression}

The regression analysis is provided in Table 4. The correlation coefficient in Table 4 is $R=$ 0.999 , indicating a favorable relationship between the variables. The result of $R$ square is 0.998 , suggests that the one independent variable account for 99.8 percent of the variation in the dependent variable.

Table 4: Model Summary ${ }^{a}$

\begin{tabular}{|c|c|c|c|c|c|c|c|c|c|}
\hline \multirow[b]{2}{*}{ Model } & \multirow[b]{2}{*}{$\mathrm{R}$} & \multirow{2}{*}{$\begin{array}{l}\text { R } \\
\text { Squa } \\
\text { re }\end{array}$} & \multirow{2}{*}{$\begin{array}{l}\text { Adjuste } \\
d \quad R \\
\text { Square }\end{array}$} & \multirow{2}{*}{$\begin{array}{l}\text { Standard } \\
\text { Error of the } \\
\text { Estimate }\end{array}$} & \multicolumn{5}{|c|}{ Change Statistics } \\
\hline & & & & & $\begin{array}{l}\text { R Square } \\
\text { Change }\end{array}$ & F Change & df1 & df2 & $\begin{array}{l}\text { Sig. F } \\
\text { Change }\end{array}$ \\
\hline 1 & $.999^{a}$ & .998 & .998 & .03645 & .998 & $\begin{array}{l}23121.25 \\
3\end{array}$ & 8 & 337 & .000 \\
\hline
\end{tabular}

a. Dependent Variable: Job security

\section{Conclusions}

The study focused on the influence of employee loyalty on job security in the oil and gas sectors in the sultanate of Oman during the COVID-19 pandemic. The data was collected through an online survey method by providing questionnaires to the respondent wherein 346 valid responses were recorded. However, the key findings from the study are as follows-

1. Most of the respondents from the oil and gas sectors in the sultanate of Oman positively support the loyalty of employees to the organization amid the COVID-19 pandemic.

2. Most of the respondents from the oil and gas sectors in the sultanate of Oman positively support the job security of the company during the COVID-19 pandemic.

3. There is a significant positive correlation of employee loyalty with job security in Oman's oil and gas sector according to Pearson Correlations Coefficient and Multiple Regression Analysis during the COVID-19 pandemic.

\section{References}

Appelbaum, S. H., \& Patton, E. (2002). Downsizing the university: bonne chance!. International Journal of Educational Management.

Chew, J. C. L. (2004). The influence of human resource management practices on the retention of core employees of Australian organisations: An empirical study (Doctoral dissertation, Murdoch University).

Gibson, J. L., Ivancevich, J. M., Donnelly, J. H., \& Konopaske, R. (2009), Organization: Behaviour, Structure, Process, McGraw-Hill Companies, Singapore.

Gilbert, G. R., \& Veloutsou, C. (2006). A cross-industry comparison of customer satisfaction. Journal of Services Marketing, 20(5), 298-308. 
MANAGEMENT SCIENCES

Vol. 11, No. 3, 2021, E-ISSN: 2225-8329 @ 2021 HRMARS

Hossain, N., Javed, M. A., Panna, M. A., Sulaiman, M., Hassan, N. \& Rahaman, S. M. (2021). Fraudulent COVID-19 Tests Are an Emerging Threat to Public Health. Asia Pacific Journal of Public Health, 33(5), 683-684.

Lee, S. M. (2012). Nurturing the future generations for oil \& gas industry. Kuala Lumpur, Malaysia: International Gas Union (IGU).

Loyalty Research Center. (2002). Definition of loyalty, Available at http://www.loyaltyresearch.com/media/thoughtperspectives/4.3.3\%20Employee\%20 L oyalty.pdf, accessed on 30th August 2021.

Mehta, S., Singh, T., Bhakar, S. S., \& Sinha, B. (2010). Employee loyalty towards organizationa study of academician. International Journal of Business Management and Economic Research, 1(1), 98-108.

Mellquist, H., \& Femermo, M. (2007), The Relationship Between the Price of Oil and Unemployment in Sweden. Student Thesis, Jonkoping University, 1-22.

Ndlouvu, N., \& Parumasur, S. B. (2005). The perceived impact of downsizing and organisational transformation on survivors. SA Journal of Industrial Psychology, 31(2), 14-21.

Newell, H., \& Dopson, S. (1996). Muddle in the middle: organizational restructuring and middle management careers. Personnel Review.

Rabby, M. I. I., Hossain, F., Akhi, I. J., \& Huda, S. N. (2021). Sexual violence against CoViD-19positive girls in India. Asia Pacific Journal of Public Health, 33(2-3), 316-317.

Rabby, M. I. I., Hossain, F., Akhi, I. J., Amin, S. S. \& Khan, A. (2020). Understanding of general people about COVID-19: A cross-sectional online survey and qualitative presentation. Türkiye Klinikleri. Tip Bilimleri Dergisi, 40(2), 203-219.

Smith, G. (2010). How to increase job satisfaction and improve employee engagement, Available at https://www.chartcourse.com/how-to-increase-job-satisfaction-andimprove-employee-engagement/, accessed on 30th August 2021.

The Dow Jones Sustainability Index. (2012). Annual report on dow jones sustainability indices. South Africa: Adventure Works Press.

Vince, D. (2005). Cultivating employee loyalty, Available at http://www.sgia.org/ feature_article/pdfs/employee_loyalty-DiCecco.pdf, accessed on 30th August 2021.

Yuki, K., Fujiogi, M. \& Koutsogiannaki, S. (2020). COVID-19 pathophysiology: A review. Clinical immunology, 215, 108427. 